\title{
Effect of Different Levels of Nitrogen, Sulphur and Foliar Application of Boron in Sunflower (Helianthus annuus L.)
}

\author{
Zineeka Singh, Gautam Ghosh and Victor Debbarma*
}

Department of Agronomy, Faculty of Agriculture, Sam Higginbottom University of Agriculture, Technology \& Sciences, Allahabad-211007, U.P., India

*Corresponding author

\author{
A B S T R A C T
}

\begin{tabular}{|l|}
\hline Key w or d s \\
Sunflower, CGR, \\
Yield and yield \\
attributes.
\end{tabular}

The experiment was conducted during the Kharif season of 2015 at Crop Research Farm, Department of Agronomy, Naini Agricultural Institute, Sam Higginbottom University of Agriculture, Technology and Sciences, Allahabad (U.P.) to study the effect of different levels of nitrogen $\left(40 \mathrm{~kg} \mathrm{ha}^{-1}, 60 \mathrm{~kg} \mathrm{ha}^{-1}\right)$, sulphur $\left(30 \mathrm{~kg} \mathrm{ha}^{-1}, 45 \mathrm{~kg} \mathrm{ha}^{-1}\right)$ and foliar application of boron (no spray of boron, $0.2 \%$ boron spray at 30 DAS, $0.2 \%$ boron spray at 30 and 45 DAS). The results recorded that the significantly higher seed yield (1477.33 $\left.\mathrm{kg} \mathrm{ha}{ }^{-1}\right)$, higher capitulum diameter $(14.93 \mathrm{~cm})$ and higher number of seeds $\left(383.33\right.$ capitulum $\left.^{-1}\right)$ in the treatment $T_{8}\left(60 \mathrm{~kg} \mathrm{ha}^{-1}\right.$ of nitrogen $+45 \mathrm{~kg} \mathrm{ha}^{-1}$ of sulphur +0.2 $\%$ foliar spray of boron at $30 \mathrm{DAS})$. It is also observed that the significantly higher number of unfilled seeds $\left(147.56\right.$ capitulum $\left.{ }^{-1}\right)$ in the treatment $T_{3}\left(60 \mathrm{~kg} \mathrm{ha}^{-1}\right.$ of nitrogen $+30 \mathrm{~kg} \mathrm{ha}^{-1}$ of sulphur). Significantly higher plant height $(130.60 \mathrm{~cm})$ was obtain in the treatment $T_{13}$ (NPK $60 \mathrm{~kg} \mathrm{ha}^{-1}$ nitrogen $+40 \mathrm{~kg} \mathrm{ha}^{-1}$ phosphorus $+40 \mathrm{~kg} \mathrm{ha}^{-1}$ potassium).

\section{Introduction}

Sunflower (Helianthus annuus Linn.) is one of the four most important annual crops grown for oil. In India sunflower is cultivated in an area of $0.9 \mathrm{~m}$ ha, with total annual production of 0.63 million tonnes and productivity of $696 \mathrm{~kg} \mathrm{ha}^{-1}$, (2011-12). The crop has the potential to yield at least 1,000 $\mathrm{kg} \mathrm{ha}{ }^{-1}$ of seeds under rainfed conditions. Under assured rainfall situations, this can be increased up to at least $1,500 \mathrm{~kg} \mathrm{ha}^{-1}$. Uttar Pradesh has the highest productivity of 2,286 $\mathrm{kg} \mathrm{ha}^{-1}$. With rapidly increasing population, improved living standard and purchasing power of the people, the demand of vegetable oil in the country is increasing at the rate of about 4 to 6\% (Agarwal, 2007).
Therefore, there is urgent need to improve the productivity of oilseed crops to bridge up the current demand-supply gap. Intensive cropping system has depleted the inherent soil fertility, leading to deficiency of important plant nutrients which finally causes poor productivity. Thus augmenting of the nutrient supply assumes prime significance to improve sunflower productivity. Sustainable production requires efficient use of inputs including adequate and balanced fertilization. The yield and its formation process depend on genetic, environmental and agronomic factors as well as the interaction between them. Nitrogen plays an important role in improving the growth, yield as well as quality of all 
crops (Ullah et al., 2010). The yield of sunflower increased by 19 to $40 \%$ in response to nitrogen (Zubillaga et al., 2002). After nitrogen, phosphorus and potassium, sulphur is the fourth nutrient, whose deficiency is widespread in India. Sulphur deficiency is observed primarily due to high crop yield and therefore higher rate of sulphur removal by crops, and lesser use of sulphur-containing fertilizers. Boron foliar sprays seemed to overcome the deleterious effects of drought by overcoming the drought-related molecular responses and consequently appeared to meliorate sunflower growth under insufficient water conditions.

\section{Materials and Methods}

The experiment was carried out during Kharif season, 2015, at the Crop Research Farm, Department of Agronomy, Naini Agricultural Institute, SHUATS, Allahabad (U.P.), located at $25^{\circ} 24^{\prime} 42^{\prime \prime} \mathrm{N}$ latitude, $81^{\circ} 50$ ' $56^{\prime \prime} \mathrm{E}$ longitude and $98 \mathrm{~m}$ altitude above mean sea level. This area is situated on the right side of the river Yamuna. The experiment was conducted in Randomized Block Design (RBD) consisting of 13 treatments in combination with 3 replication and was laid out with a different treatment allocated randomly in each replication.

The plot size of each treatment was $5 \mathrm{~m} \times 3 \mathrm{~m}$. Factors are two levels of nitrogen $\left(40 \mathrm{~kg} \mathrm{ha}^{-1}\right.$ and $\left.60 \mathrm{~kg} \mathrm{ha}^{-1}\right)$, two levels of sulphur $(30 \mathrm{~kg}$ $\mathrm{ha}^{-1}$ and $45 \mathrm{~kg} \mathrm{ha}^{-1}$ ) and three levels of boron (no spray of boron, $0.2 \%$ boron spray at 30 days after sowing (DAS) and $0.2 \%$ boron spray at 30 and 45 DAS). The $\mathrm{N}$ and $\mathrm{S}$ were supplied in the form of urea and gypsum. Foliar application of sunflower was done through borax. Nitrogen was applied in split doses. First half was applied as basal and second by broadcasting. Sulphur application was done as basal at the time of sowing. The hybrid seed Bhaskar was sown on 12 August
2015 by maintaining a spacing of $60 \mathrm{~cm} \times$ $30 \mathrm{~cm}$. Harvesting was done taking $1 \mathrm{~m}^{2}$ area from each plot. And from it three plants were randomly selected for recording growth and yield parameters. Total oil content obtained from the seeds was recorded in percentage. The percentage of oil content in seeds was determined by solvent extraction methods in soxhlet's apparatus. The data were subjected to statistical analysis by analysis of variance method (Gomez and Gomez, 1976).

\section{Results and Discussion}

\section{Crop growth rate (CGR)}

At 45-60 DAS interval, the highest CGR $\left(11.51 \mathrm{~g} \mathrm{~m}^{-2}\right.$ day $\left.^{-1}\right)$ was obtained in $\mathrm{T}_{3}(60 \mathrm{~kg}$ $\mathrm{ha}^{-1}$ of nitrogen $+30 \mathrm{~kg} \mathrm{ha}^{-1}$ of sulphur) which was $6.57 \%$ higher than the lowest CGR $\left(10.80 \mathrm{~g} \mathrm{~m}^{-2} \mathrm{day}^{-1}\right)$ though it was nonsignificant. At 30-45 DAS highest CGR (4.15 $\mathrm{g} \mathrm{m}^{-2}$ day $\left.^{-1}\right)$ was observed in $\mathrm{T}_{13}\left(60 \mathrm{~kg} \mathrm{ha}^{-1}\right.$ nitrogen $+40 \mathrm{~kg} \mathrm{ha}^{-1}$ phosphorus $+40 \mathrm{~kg} \mathrm{ha}^{-1}$ potassium $)$. However, $\mathrm{T}_{12}\left(60 \mathrm{~kg} \mathrm{ha}^{-1}\right.$ of nitrogen $+45 \mathrm{~kg} \mathrm{ha}^{-1}$ of sulphur $+0.2 \%$ foliar spray of boron at 30 DAS and 45 DAS), $T_{11}$ $\left(60 \mathrm{~kg} \mathrm{ha}^{-1}\right.$ of nitrogen $+30 \mathrm{~kg} \mathrm{ha}^{-1}$ of sulphur $+0.2 \%$ foliar spray of boron at 30 DAS and 45 DAS), $\mathrm{T}_{10}\left(40 \mathrm{~kg} \mathrm{ha}^{-1}\right.$ of nitrogen $+45 \mathrm{~kg}$ $\mathrm{ha}^{-1}$ of sulphur $+0.2 \%$ foliar spray of boron at 30 DAS and 45 DAS), T 8 (60 kg ha ${ }^{-1}$ of nitrogen $+45 \mathrm{~kg} \mathrm{ha}^{-1}$ of sulphur $+0.2 \%$ foliar spray of boron at $30 \mathrm{DAS}), \mathrm{T}_{5}\left(40 \mathrm{~kg} \mathrm{ha}^{-1}\right.$ of nitrogen $+30 \mathrm{~kg} \mathrm{ha}^{-1}$ of sulphur $+0.2 \%$ foliar spray of boron at $30 \mathrm{DAS}), \mathrm{T}_{4}\left(60 \mathrm{~kg} \mathrm{ha}^{-1}\right.$ of nitrogen $+45 \mathrm{~kg} \mathrm{ha}^{-1}$ of sulphur), $\mathrm{T}_{2}(40 \mathrm{~kg}$ $\mathrm{ha}^{-1}$ of nitrogen $+45 \mathrm{~kg} \mathrm{ha}^{-1}$ of sulphur) and $\mathrm{T}_{1}$ (40 kg ha $\mathrm{kf}^{-1}$ of nitrogen $+30 \mathrm{~kg} \mathrm{ha}^{-1}$ of sulphur) were found to be statistically at par with $\mathrm{T}_{13}$. At $15-30$ DAS significantly higher CGR $\left(1.14 \mathrm{~g} \mathrm{~m}^{-2} \mathrm{day}^{-1}\right)$ was found in treatment $\mathrm{T}_{7}\left(60 \mathrm{~kg} \mathrm{ha}^{-1}\right.$ of nitrogen+ $30 \mathrm{~kg} \mathrm{ha}^{-1}$ of sulphur $+0.2 \%$ foliar spray of boron at 30 DAS $)$. However, treatment $\mathrm{T}_{8}\left(60 \mathrm{~kg} \mathrm{ha}^{-1}\right.$ of nitrogen $+45 \mathrm{~kg} \mathrm{ha}^{-1}$ of sulphur $+0.2 \%$ foliar 
spray of boron at 30 DAS) was observed statistically at par with $T_{7}$. In this case it was seen that there was an increase in CGR from 30-45 DAS interval to 45-60 DAS interval as top dressing of urea was done at 50 DAS (Table 1). Nitrogen fertilizer showed positive and linear effect in the production of total dry matter (Rasool et al., 2015).

Nitrogen application had durable consequence on the improvement and increase of leaf area in terms of radiation interception (Nasim et al., 2012). Nitrogen and sulphur plays manifold roles in oilseed crops. The availability of one nutrient in addition to its direct role in promoting growth and yield regulates the activity of another.

\section{Plant height}

The data revealed that there was an increase in plant height at 60 DAS. Significantly higher plant height $(130.60 \mathrm{~cm})$ was observed in $\mathrm{T}_{13}\left(60 \mathrm{~kg} \mathrm{ha}^{-1}\right.$ nitrogen $+40 \mathrm{~kg} \mathrm{ha}^{-1}$ phosphorus $+40 \mathrm{~kg} \mathrm{ha}$ potassium). However, $\mathrm{T}_{7}\left(60 \mathrm{~kg} \mathrm{ha}^{-1}\right.$ of nitrogen $+30 \mathrm{~kg}$ $\mathrm{ha}^{-1}$ of sulphur $+0.2 \%$ foliar spray of boron at 30 DAS $)$ and $\mathrm{T}_{11}\left(60 \mathrm{~kg} \mathrm{ha}^{-1}\right.$ of nitrogen + $30 \mathrm{~kg} \mathrm{ha}^{-1}$ of sulphur $+0.2 \%$ foliar spray of boron at 30 DAS and 45 DAS) was found to be statistically at par to $T_{13}\left(60 \mathrm{~kg} \mathrm{ha}^{-1}\right.$ nitrogen $+40 \mathrm{~kg} \mathrm{ha}^{-1}$ phosphorus $+40 \mathrm{~kg} \mathrm{ha}^{-1}$ potassium) (Table 2). According to Kumar et al., (2011), plant height increases with sulphur uptake as it increases cell multiplication, elongation and cell expansion throughout the entire period of crop growth. Nitrogen effects cell elongation as well as brings the principle component of protein, enzymes, hormones, vitamins, chlorophyll and it accelerates the meristamatic activity of plant which leads to progressive increase in internode length, protein synthesis and photosynthetic area leading to higher plant height and dry matter production (Biswas and Poddar, 2015).

\section{Yield and yield attributes}

\section{Capitulum diameter}

There was an increase in capitulum diameter. The treatment $\mathrm{T}_{8}\left(60 \mathrm{~kg} \mathrm{ha}^{-1}\right.$ of nitrogen +45 $\mathrm{kg} \mathrm{ha}{ }^{-1}$ of sulphur $+0.2 \%$ foliar spray of boron at 30 DAS) recorded significantly higher capitulum diameter $(14.93 \mathrm{~cm})$. However, $\mathrm{T}_{6}\left(40 \mathrm{~kg} \mathrm{ha}^{-1}\right.$ of nitrogen $+45 \mathrm{~kg}$ $\mathrm{ha}^{-1}$ of sulphur $+0.2 \%$ foliar spray of boron at 30 DAS) was found to be statistically at par with $\mathrm{T}_{8}\left(60 \mathrm{~kg} \mathrm{ha}^{-1}\right.$ of nitrogen $+45 \mathrm{~kg} \mathrm{ha}^{-1}$ of sulphur $+0.2 \%$ foliar spray of boron at 30 DAS). (Table 2) Sadiq et al., (2000) uncovered that the increase in capitulum diameter with nitrogen and boron application by means of efficient assimilates portioning towards reproductive parts. But the diameter of the capitulum was reduced comparatively in size in all treatments as the $2^{\text {nd }}$ split dose of nitrogen was given at 51 DAS instead of 30 DAS due unavailability of irrigation. Sulphur application was also highly beneficial in improving the capitulum diameter. Since it is an element in evitable for oilseed, its greater diversion is required toward the head (Shekhawat and Shivay, 2008).

\section{No. of seeds capitulum ${ }^{-1}$}

There was an increase in No. of seeds capitulum $^{-1}$. The treatment $\mathrm{T}_{8}\left(60 \mathrm{~kg} \mathrm{ha}{ }^{-1}\right.$ of nitrogen $+45 \mathrm{~kg} \mathrm{ha}^{-1}$ of sulphur $+0.2 \%$ foliar spray of boron at 30 DAS) recorded significant higher number of seeds per capitulum (383.33). However, $\mathrm{T}_{3}\left(60 \mathrm{~kg} \mathrm{ha}^{-1}\right.$ of nitrogen $+30 \mathrm{~kg} \mathrm{ha}^{-1}$ of sulphur) was found to be statistically at par with $\mathrm{T}_{8}\left(60 \mathrm{~kg} \mathrm{ha}^{-1}\right.$ of nitrogen $+45 \mathrm{~kg} \mathrm{ha}^{-1}$ of sulphur $+0.2 \%$ foliar spray of boron at 30 DAS) (Table 2). According to Jat and Giri (2000), application of nitrogen significantly improved the size of capitulum, seeds per capitulum and test weight due to synthesis of more photosynthates. 
Table.1 Effect of different levels of nutrients on crop growth rate of sunflower crop

\begin{tabular}{|c|c|c|c|c|}
\hline & \multirow{2}{*}{ TREATMENTS } & \multicolumn{3}{|c|}{$\operatorname{CGR}\left(\mathrm{g} \mathrm{m}^{-2}\right.$ day $\left.^{-1}\right)$} \\
\hline & & 15-30 DAS & 30-45 DAS & 45-60 DAS \\
\hline $\mathrm{T}_{1}$ & $40 \mathrm{~kg} \mathrm{ha}^{-1}$ of nitrogen $+30 \mathrm{~kg} \mathrm{ha}^{-1}$ of sulphur & 0.96 & 3.80 & 11.34 \\
\hline $\mathrm{T}_{2}$ & $40 \mathrm{~kg} \mathrm{ha}^{-1}$ of nitrogen $+45 \mathrm{~kg} \mathrm{ha}^{-1}$ of sulphur & 0.82 & 3.76 & 11.38 \\
\hline $\mathrm{T}_{3}$ & $60 \mathrm{~kg} \mathrm{ha}^{-1}$ of nitrogen $+30 \mathrm{~kg} \mathrm{ha}^{-1}$ of sulphur & 0.91 & 3.60 & 11.51 \\
\hline $\mathrm{T}_{4}$ & $60 \mathrm{~kg} \mathrm{ha}^{-1}$ of nitrogen $+45 \mathrm{~kg} \mathrm{ha}^{-1}$ of sulphur & 0.89 & 3.99 & 11.43 \\
\hline $\mathrm{T}_{5}$ & $40 \mathrm{~kg} \mathrm{ha}^{-1}$ of nitrogen $+30 \mathrm{~kg} \mathrm{ha}^{-1}$ of sulphur $+0.2 \%$ foliar spray of boron at $30 \mathrm{DAS}$ & 0.91 & 3.76 & 11.29 \\
\hline $\mathrm{T}_{6}$ & $40 \mathrm{~kg} \mathrm{ha}^{-1}$ of nitrogen $+45 \mathrm{~kg} \mathrm{ha}^{-1}$ of sulphur $+0.2 \%$ foliar spray of boron at 30 DAS & 0.98 & 3.63 & 11.47 \\
\hline $\mathrm{T}_{7}$ & $60 \mathrm{~kg} \mathrm{ha}^{-1}$ of nitrogen $+30 \mathrm{~kg} \mathrm{ha}^{-1}$ of sulphur $+0.2 \%$ foliar spray of boron at $30 \mathrm{DAS}$ & 1.14 & 3.39 & 11.46 \\
\hline $\mathrm{T}_{8}$ & $60 \mathrm{~kg} \mathrm{ha}^{-1}$ of nitrogen $+45 \mathrm{~kg} \mathrm{ha}^{-1}$ of sulphur $+0.2 \%$ foliar spray of boron at $30 \mathrm{DAS}$ & 1.08 & 4.03 & 11.39 \\
\hline $\mathrm{T}_{9}$ & $40 \mathrm{~kg} \mathrm{ha}^{-1}$ of nitrogen $+30 \mathrm{~kg} \mathrm{ha}^{-1}$ of sulphur $+0.2 \%$ foliar spray of boron at 30 DAS and 45 DAS & 0.85 & 3.70 & 11.50 \\
\hline $\mathrm{T}_{10}$ & $40 \mathrm{~kg} \mathrm{ha}^{-1}$ of nitrogen $+45 \mathrm{~kg} \mathrm{ha}^{-1}$ of sulphur $+0.2 \%$ foliar spray of boron at 30 DAS and 45 DAS & 0.83 & 3.84 & 11.49 \\
\hline $\mathrm{T}_{11}$ & $60 \mathrm{~kg} \mathrm{ha}^{-1}$ of nitrogen $+30 \mathrm{~kg} \mathrm{ha}^{-1}$ of sulphur $+0.2 \%$ foliar spray of boron at 30 DAS and 45 DAS & 0.99 & 3.91 & 11.13 \\
\hline $\mathrm{T}_{12}$ & $60 \mathrm{~kg} \mathrm{ha}^{-1}$ of nitrogen $+45 \mathrm{~kg} \mathrm{ha}^{-1}$ of sulphur $+0.2 \%$ foliar spray of boron at 30 DAS and 45 DAS & 1.03 & 4.12 & 10.94 \\
\hline \multirow[t]{4}{*}{$\mathrm{T}_{13}$} & NPK $\left(60 \mathrm{~kg} \mathrm{ha}^{-1}\right.$ nitrogen $+40 \mathrm{~kg} \mathrm{ha}^{-1}$ phosphorus $+40 \mathrm{~kg} \mathrm{ha}^{-1}$ potassium 1$)$ & 0.98 & 4.15 & 10.80 \\
\hline & F test & $\mathrm{S}$ & $\mathrm{S}$ & NS \\
\hline & S.Ed. \pm & 0.03 & 0.19 & 0.26 \\
\hline & $\mathrm{CD}(\mathrm{P}=0.05)$ & 0.07 & 0.39 & 0.54 \\
\hline
\end{tabular}




\section{Int.J.Curr.Microbiol.App.Sci (2017) 6(10): 1336-1342}

Table.2 Effect of different levels nutrient sources on plant height, yield and yield attributes

\begin{tabular}{|c|c|c|c|c|c|c|}
\hline $\begin{array}{l}\text { S. } \\
\text { No. }\end{array}$ & TREATMENTS & $\begin{array}{c}\text { Plant } \\
\text { height } \\
(\mathbf{c m})\end{array}$ & $\begin{array}{l}\text { Capitulum } \\
\text { diameter } \\
(\mathbf{c m})\end{array}$ & $\begin{array}{l}\text { No. of seeds } \\
\text { capitulum }^{-1}\end{array}$ & $\begin{array}{l}\text { No. of unfilled } \\
\text { seeds } \\
\text { capitulum }\end{array}$ & $\begin{array}{c}\text { Seed } \\
\text { Yield }(\mathbf{k g} \\
\left.\text { ha }^{-1}\right)\end{array}$ \\
\hline $\mathrm{T}_{1}$ & $40 \mathrm{~kg} \mathrm{ha}^{-1}$ of nitrogen $+30 \mathrm{~kg} \mathrm{ha}^{-1}$ of sulphur & 94.40 & 12.07 & 300.11 & 146.67 & 1288.67 \\
\hline $\mathrm{T}_{2}$ & $40 \mathrm{~kg} \mathrm{ha}^{-1}$ of nitrogen $+45 \mathrm{~kg} \mathrm{ha}^{-1}$ of sulphur & 94.27 & 11.80 & 284.22 & 145.00 & 1294.67 \\
\hline $\mathrm{T}_{3}$ & $60 \mathrm{~kg} \mathrm{ha}^{-1}$ of nitrogen $+30 \mathrm{~kg} \mathrm{ha}^{-1}$ of sulphur & 88.73 & 11.90 & 350.33 & 147.56 & 1333.00 \\
\hline $\mathrm{T}_{4}$ & $60 \mathrm{~kg} \mathrm{ha}^{-1}$ of nitrogen $+45 \mathrm{~kg} \mathrm{ha}^{-1}$ of sulphur & 98.20 & 11.16 & 329.11 & 145.56 & 1261.67 \\
\hline $\mathrm{T}_{5}$ & $\begin{array}{l}40 \mathrm{~kg} \mathrm{ha}^{-1} \text { of nitrogen }+30 \mathrm{~kg} \mathrm{ha}^{-1} \text { of sulphur }+0.2 \% \text { foliar spray of boron } \\
\text { at } 30 \text { DAS }\end{array}$ & 94.47 & 12.06 & 329.44 & 128.89 & 1347.00 \\
\hline $\mathrm{T}_{6}$ & $\begin{array}{l}40 \mathrm{~kg} \mathrm{ha}^{-1} \text { of nitrogen }+45 \mathrm{~kg} \mathrm{ha}^{-1} \text { of sulphur }+0.2 \% \text { foliar spray of boron } \\
\text { at } 30 \text { DAS }\end{array}$ & 105.67 & 13.70 & 321.89 & 105.67 & 1413.67 \\
\hline $\mathrm{T}_{7}$ & $\begin{array}{l}60 \mathrm{~kg} \mathrm{ha}^{-1} \text { of nitrogen }+30 \mathrm{~kg} \mathrm{ha}^{-1} \text { of sulphur }+0.2 \% \text { foliar spray of boron } \\
\text { at } 30 \text { DAS }\end{array}$ & 114.40 & 11.51 & 321.78 & 109.33 & 1352.33 \\
\hline $\mathrm{T}_{8}$ & $\begin{array}{l}60 \mathrm{~kg} \mathrm{ha}^{-1} \text { of nitrogen }+45 \mathrm{~kg} \mathrm{ha}^{-1} \text { of sulphur }+0.2 \% \text { foliar spray of boron } \\
\text { at } 30 \text { DAS }\end{array}$ & 97.07 & 14.93 & 383.33 & 103.78 & 1477.33 \\
\hline $\mathrm{T}_{9}$ & $\begin{array}{l}40 \mathrm{~kg} \mathrm{ha}^{-1} \text { of nitrogen }+30 \mathrm{~kg} \mathrm{ha}^{-1} \text { of sulphur }+0.2 \% \text { foliar spray of boron } \\
\text { at } 30 \text { DAS and } 45 \text { DAS }\end{array}$ & 104.87 & 12.44 & 341.22 & 115.89 & 1306.33 \\
\hline $\mathrm{T}_{10}$ & $\begin{array}{l}40 \mathrm{~kg} \mathrm{ha}^{-1} \text { of nitrogen }+45 \mathrm{~kg} \mathrm{ha}^{-1} \text { of sulphur }+0.2 \% \text { foliar spray of boron } \\
\text { at } 30 \text { DAS and } 45 \text { DAS }\end{array}$ & 95.80 & 10.64 & 333.89 & 115.89 & 1404.00 \\
\hline $\mathrm{T}_{11}$ & $\begin{array}{l}60 \mathrm{~kg} \mathrm{ha}^{-1} \text { of nitrogen }+30 \mathrm{~kg} \mathrm{ha}^{-1} \text { of sulphur }+0.2 \% \text { foliar spray of boron } \\
\text { at } 30 \text { DAS and } 45 \text { DAS }\end{array}$ & 122.76 & 11.71 & 335.89 & 118.89 & 1354.00 \\
\hline $\mathrm{T}_{12}$ & $\begin{array}{l}60 \mathrm{~kg} \mathrm{ha}^{-1} \text { of nitrogen }+45 \mathrm{~kg} \mathrm{ha}^{-1} \text { of sulphur }+0.2 \% \text { foliar spray of boron } \\
\text { at } 30 \text { DAS and } 45 \text { DAS }\end{array}$ & 105.60 & 11.08 & 294.44 & 99.67 & 1364.00 \\
\hline \multirow[t]{4}{*}{$\mathrm{T}_{13}$} & NPK (60 kg ha ${ }^{-1}$ nitrogen $+40 \mathrm{~kg} \mathrm{ha}^{-1}$ phosphorus $+40 \mathrm{~kg} \mathrm{ha}^{-1}$ potassium $)$ & 130.60 & 8.95 & 261.33 & 145.67 & 1061.67 \\
\hline & F test & $\mathrm{S}$ & $S$ & $\mathrm{~S}$ & $S$ & $\mathrm{~S}$ \\
\hline & S.Ed. $( \pm)$ & 9.04 & 0.82 & 18.09 & 3.90 & 31.46 \\
\hline & $\mathrm{CD}(\mathrm{P}=0.05)$ & 18.67 & 1.70 & 37.34 & 8.05 & 64.94 \\
\hline
\end{tabular}


Boron fertilizers applied as foliar spray to sunflower plants can have significant effects on seed set and seed yield. Similar findings were recorded by Krudnak et al., 2013).

\section{No. of unfilled seedscapitulum ${ }^{-1}$}

There was an increase in No. of Unfilled seeds. The treatment $\mathrm{T}_{3}(60 \mathrm{~kg} \mathrm{ha}$ of nitrogen $+30 \mathrm{~kg} \mathrm{ha}^{-1}$ of sulphur) recorded significantly higher number of unfilled seeds (147.56). However, $\mathrm{T}_{1}$ (40 $\mathrm{kg} \mathrm{ha}^{-1}$ of nitrogen $+30 \mathrm{~kg} \mathrm{ha}^{-1}$ of sulphur), $\mathrm{T}_{2}$ (40 kg ha ${ }^{-1}$ of nitrogen $+45 \mathrm{~kg} \mathrm{ha}^{-1}$ of sulphur), $\mathrm{T}_{4}(60 \mathrm{~kg}$ $\mathrm{ha}^{-1}$ of nitrogen $+45 \mathrm{~kg} \mathrm{ha}^{-1}$ of sulphur) and $\mathrm{T}_{13}\left(60 \mathrm{~kg} \mathrm{ha}^{-1}\right.$ nitrogen $+40 \mathrm{~kg} \mathrm{ha}^{-1}$ phosphorus $+40 \mathrm{~kg} \mathrm{ha}^{-1}$ potassium) were found to be statistically at par with $T_{3}(60 \mathrm{~kg}$ $\mathrm{ha}^{-1}$ of nitrogen $+30 \mathrm{~kg} \mathrm{ha}^{-1}$ of sulphur). Whereas, the lowest number of unfilled seeds (99.67) was found in $T_{12}\left(60 \mathrm{~kg} \mathrm{ha}^{-1}\right.$ of nitrogen $+45 \mathrm{~kg} \mathrm{ha}^{-1}$ of sulphur $+0.2 \%$ foliar spray of boron at 30 DAS and 45 DAS) (Table 2). Boron application increases seed yield of sunflower owing to increase in seed filling and thus decreasing the number of unfilled seeds. Similar findings were recorded by Almery et al., 2011. Under well nitrogen availability, boron has good impact on better development of pollens, pollen germination, anther viability, anthesis, cell division, enhanced enzymatic activity and more availability of sugars; end resulted in more production of seeds (Maqshood and Shezad, 2015). It was observed that the No. of unfilled seeds increased because of the prevailing drought conditions. The reason being that many physiological processes of the plant was reduced due to moisture stress as well as due to decrease in number of pollinating agents (insects) due to undue climatic conditions which prevailed over the region.

\section{Seed yield}

$60 \mathrm{~kg} \mathrm{ha}^{-1}$ of nitrogen $+45 \mathrm{~kg} \mathrm{ha}^{-1}$ of sulphur $+0.2 \%$ foliar spray of boron at 30 DAS recorded significantly higher seed yield $\left(1477.33 \mathrm{~kg} \mathrm{ha}^{-1}\right)$. However, $\mathrm{T}_{6}\left(40 \mathrm{~kg} \mathrm{ha}^{-1}\right.$ of nitrogen $+45 \mathrm{~kg} \mathrm{ha}^{-1}$ of sulphur $+0.2 \%$ foliar spray of boron at 30 DAS) was found to be statistically at par with $\mathrm{T}_{8}\left(60 \mathrm{~kg} \mathrm{ha}^{-1}\right.$ of nitrogen $+45 \mathrm{~kg} \mathrm{ha}^{-1}$ of sulphur $+0.2 \%$ foliar spray of boron at 30 DAS) (Table 2). Sulphur is known to play vital role in formation of amino acids. Higher dry matter accumulation and better translocation of photosynthates led to increase in yield components which in turn resulted in increase in seed yield. According to Almery et al., 2011, seed yield increased linearly in response to boron. The seed yield was comparatively low because the yield attributes did not develop to their full potential because of the erratic condition.

Based on the above findings it can be concluded that for obtaining good seed yield from Kharif sunflower, $60 \mathrm{~kg} \mathrm{ha}{ }^{-1}$ of nitrogen, $45 \mathrm{~kg} \mathrm{ha}^{-1}$ of sulphur and $0.2 \%$ foliar spray of boron at 30 DAS, can significantly increase capitulum diameter, No. of seeds capitulum ${ }^{-1}$, and seed yield of the crop. Thus for improving yield of sunflower achenes during drought conditions which prevailed during this crop growth period, application of sulphur at $\left(40 \mathrm{~kg} \mathrm{ha}^{-1}\right)$ and foliar spray application of boron $(0.2 \%$ at 30 DAS) is also indispensable along with NPK application.

\section{References}

Agarwal, R.C., Indian edible oil scenario. (In:) Souvenir of National Symposium on "Changing global vegetable oil scenario-issues and challenges before India". Directorate of Oilseeds Research, Hyderabad, January 29-31, 2007. pp. 27-32 2007.

Al-Amery, M., Hamza, J.H., and Fuller, M.P.: Effect of Boron Foliar Application on Reproductive Growth of Sunflower (Helianthus annuus L.)International Journal of Agronomy Volume 2011, 
Article ID 2307122011.

Biswas, B., and Poddar, R.: Yield and nutrients uptake of sunflower (Helianthus annuus L.) as influenced by different level of nitrogen and sulphur. The Bioscan 10(1): 439-444, 2015 (Supplement On Agronomy 2015.

Gomez, K. A., and Gomez, A. A.: Three or more factor experiment. In: Statistical Procedure for Agricultural Research 2nd edition, p. 139 -141 1976.

Jat, R., and Giri, G.: Influence of nitrogen and weed control measures on weed growth and seed and oil yields of sunflower (Helianthus annuus L.). Indian Journal of Agronomy 45(1): 193-198 2000.

Krudnak, Arpron, Wonprasaid, Sodcho and Thitiporn, Machikowa: Boron affects pollen viability and seed set in sunflowers. African Journal of Agricultural Research Vol. 8(2), pp. 162-166, 2013.

Kumar, Satish, Tewari, S.K. and Singh, S.S. 2011. Effect of Sources and Levels of Sulphur and Spacing on the Growth, Yield and Quality of Spring Sunflower (Helianthus annuus). Indian Journal of Agronomy 56 (3): 242-246

Maqsoodand Shehzad, Asif: Integrated nitrogen and boron fertilization improves the productivity and oil quality of sunflower grown in a calcareous soil. Turk Journal of FieldCrops 20(2): 213-222 2015.

Nasim, W., Ahmad, A. Bano, A. Olatinwo, R. Usman, M. Khaliq. T., Wajid, A., Hammad, H.M., Mubeen, M., and Hussain, M. 2012. Effect of nitrogen on yield and quality of sunflower (Helianthus annuus L.) hybrids under sub humid conditions of Pakistan. American Journal of plant Sciences, 3: 243-251

Rasool, K., Wajid, A., Sanaullah, Ghaffar, A., Shoaib, M, Arshad, M.and Abbas, S.: Optimizing Nitrogen Rate And Planting Density For Sunflower Under Irrigated Conditions of Punjab. SAARC Journal of Agriculture, 13 (1): 174-187, 2015.

Sadiq, S.A., M., Shahi, A., Jan and S.N.U., Din: Effect of various levels of nitrogen, phosphorus and potassium (NPK) on growth, yield and components of sunflower. Pakistan Journalof Biological Sciences 3: 338339, 2000.

Shekhawat, K., and Shivay, Y. S.: Effect of nitrogen sources of sulphur and boron levels on productivity, nutrient uptake and quality of sunflower (Helianthus annuus). Indian Journal of Agronomy. 53(2): 129-134, 2008.

Ullaha, M.A., Anwar, M. and Rana, A.S.: Effect of nitrogen fertilization and harvesting intervals on the yield and forage quality of elephant grass (Pennisetum purpureum) under mesic climate of Pothowar plateau. Pakistan Journal of Agricultural Sciences 47: 231-234, 2010.

Zubillaga, M.M., Aristi, J.P., Lavado, R.S.: Effect of phosphorus and nitrogen fertilization on sunflower (Helianthus annuиs L.) nitrogen uptake and yield. Journal of Agronomy and Crop Science, 188: 267-274, 2002.

\section{How to cite this article:}

Zineeka Singh, Gautam Ghosh and Victor Debbarma. 2017. Effect of Different Levels of Nitrogen, Sulphur and Foliar Application of Boron in Sunflower (Helianthus annuus L.). Int.J.Curr.Microbiol.App.Sci. 6(10): 1336-1342. doi: https://doi.org/10.20546/ijcmas.2017.610.157 